\title{
HOW INFORMATION HELPS ON INCREASING STUDENTS' UNDERSTANDING OF ADOLESCENT REPRODUCTIVE HEALTH AT SCHOOL
}

\author{
Insan Suwanto ${ }^{1)}$ \\ 1) STKIP Singkawang, Indonesia \\ E-mail:insansuwanto@gmail.com
}

\begin{abstract}
This study aims to describe the level of students' understanding of adolescent reproductive health and to examine how the influence of information on their level of understanding. The research used was pre-experimental designs with a one-group pretest-posttest design with a total sample of 41 people. The instruments used in this study were the Students' Reproductive Health Understanding Level Scale $(\alpha=0.328)$ and interviews. Data were analyzed using descriptive percentage formula and Wilcoxon signed rank test. The results showed that the level of understanding of students about adolescent reproductive health is in the low criteria with an average value of 55.75\%. Based on the results of the Wilcoxon signed rank test, it shows that there is an effect of providing information helps on the level of understanding of adolescent reproductive health. With the provision of information helps, students can gain an understanding of the material presented, namely the understanding of women's reproductive health. In addition, there is a prevention function so that students are able to avoid irresponsible behavior towards their own reproductive health.
\end{abstract}

Keywords: Information; adolescent reproductive health; students' level of understanding

\section{INTRODUCTION}

Basically health is something that is important for everyone. Health is a state of health, both physically, mentally, spiritually and socially that enables everyone to live socially and economically productive lives. Health is something that must be prioritized in everyday life. One of them is physical health, namely reproductive health. Understanding reproductive health is very important for everyone to have. According to Purwanto, understanding is the level of ability that expects students to be able to understand the meaning or concepts, situations and facts they know (Dini, Wijaya, \& Sugandi, 2018).

According to Pinem, reproductive health is a healthy condition concerning the reproductive system, function, and process possessed by adolescents. The definition of healthy here does not merely mean free from disease or free from disability, but also mentally healthy (Hazar, Astuti, \& Yuline, 2013). Meanwhile, according to Nurfajriyah, reproductive health is a complete physical, mental and social condition, not only free from disease or disability in all aspects related to the reproductive system, its functions and processes (Astika \& Sutijono, 2013). Based on the opinion above, it can be concluded that understanding reproductive health is the level of ability that expects students to be able to understand a healthy condition concerning the reproductive system, function, and process possessed by adolescents physically, mentally and socially.
The female reproductive organ is an interesting discussion because of its fundamental function in human life, which functions for recreation (entertainment), re-creation (recreation), and give birth generations. Because it functions fundamentally, the health of these organs must be maintained, and their rights need to be guaranteed so that they remain healthy for themselves, free from pressure and control from parties who regard them as mere objects (Astika \& Sutijono, 2013).

Reproductive health is very important for every teenager, especially in adolescent students. Hygiene and health of the reproductive organs are the things that will determine whether or not the seeds of the next generation are good or not. In line with this, the International Conference on Population and Development (ICDP) within the National Family Planning Coordinating Board $(B K K B N)$, is of the opinion that reproduction has the term re which means return, production means to produce. So reproduction means a process of continuing offspring in humans for the preservation of human life (Azhar, 2017). In this context, adolescents must pay attention to and maintain good reproductive health in order to avoid unwanted diseases.

Information about reproductive health is very important to be given to teenagers today, both in the family environment and in the educational environment. Adolescents need to know about reproductive health in order to have broad information about the reproductive process and the various factors that surround it. Adolescents must be able to know several indicators of understanding adolescent reproductive 
health, such as adolescents having an understanding of the need for maintaining the cleanliness of reproductive organs, understanding reproductive processes and the impact of irresponsible behavior such as unwanted pregnancy, abortion, transmission of sexually transmitted diseases including HIV. With the correct information, it is hoped that adolescents will have a responsible attitude and behavior regarding their reproductive health.

The main problems of Adolescent Reproductive Health in Indonesia are the lack of information on reproductive health, the problem of shifting adolescent sexual behavior, poor health helps and unsupported legislation. Adolescent knowledge about reproductive health issues is still relatively low. Adolescent reproductive health 2002-2003 showed that $21 \%$ of women and $28 \%$ of men did not know any signs of physical changes from the opposite sex. Lack of knowledge about basic biology in adolescents reflects a lack of knowledge about the risks associated with their bodies and how to avoid them (Hazar, Astuti, \& Yuline, 2013).

Based on the results of research shows that the level of understanding of students before being provided with adolescent reproductive health information helps is $59.25 \%$ of students who have a poor understanding of reproductive health, and $18.52 \%$ of students have a poor understanding of reproductive health. reproductive health (Sari, Munir, \& Munifah, 2017). The lack of knowledge about reproductive processes, the importance of maintaining the cleanliness of the reproductive organs, and the impact of irresponsible behavior causes some teenagers to experience problems such as teenagers being less aware of the importance of maintaining their reproductive health (Widyastuti, 2009).

Problems that occur in adolescent reproductive health can be in the form of sex before marriage, dropping out of school due to pregnancy, irresponsible partners, use of contraceptives, abortion, HIV/AIDS infection, sexually transmitted diseases and the use of illegal drugs (Ernawati, 2018). So that the problem of adolescent reproductive health that is currently being highlighted is the increasing incidence of HIV/AIDS and the maternal mortality rate in adolescents. In Bali, the incidence of HIV/AIDS was recorded at 1615 cases and $50 \%$ of this number was in the age range of 19-25 years. The age distribution of the incidence of HIV/AIDS is quite surprising because the increase occurred in the younger age group (Wijaya, Agutini, \& Tisna, 2014).

Based on the data above, it can be seen that there are still many teenagers who still do not know and understand the importance of reproductive health, especially for adolescents. The results of research it appears that most students do not understand and understand reproductive health, because students think that this is a taboo subject to talk about, so students do not understand reproductive health. Therefore, it is at this age that students must be given this information because the earlier they are given information, they will better maintain their reproductive health (Hazar, Astuti, \& Yuline, 2013).

One of the efforts that can be done to overcome problems regarding the understanding of adolescent reproductive health in school is through information helps. In an effort to help adolescent students have the knowledge, attitudes and behaviors that are responsible for their reproductive health, information help activities as part of the operation of the adolescent reproductive health program are very appropriate activities to use.

Information helps are helps that help students receive and understand various personal, social, learning, career/position information, and further education (Sukitman, 2015). Furthermore, according to Winkel (in Tohirin, 2014), information help is a help that seeks to meet the individual's lack of information they need. Based on the opinion above, it can be concluded that information help is an assistance help provided to students to receive and understand various information needed by each student.

\section{METHODS}

The research method used by the researcher is a quantitative method using a pre-experimental One-Group Pretest-Posttest Design. Pretest is given to students with the aim of knowing the level of understanding of students about reproductive health before being given treatment. The treatment used was information help about female adolescent reproductive health. The aim is to find out whether there is an influence on the understanding of adolescent reproductive health, especially for students after being given treatment. Then give another test (posttest) to determine the level of students' understanding of reproductive health after being given treatment. The aim is to measure changes that occur in students after being given treatment so that the success rate of treatment can be known. The calculation of the change score after treatment is done by comparing the results before and after help delivery.

The determination of the sample was chosen from one of the upper secondary schools in the city of Singkawang which was considered to be in dire need of information helps about understanding adolescent reproductive health, namely through the results of the questionnaire results of the Student Problem Needs Instrument which amounted to 41 people.

In the research data collection instrument, the researcher used a reproductive health understanding scale instrument $(n=33 ;=0.328>0.195)$ and an interview guide instrument. In the interview guide data collection instrument, the researcher used an unstructured interview guide because the interview was free where the researcher did not use an interview guide that had been systematically and completely arranged for data collection.

In this study, there are two types of data analysis, namely descriptive percentage analysis and inferential statistical analysis. To test the formulation of the first problem, namely "how much is the level of students' understanding of adolescent reproductive health before being provided with information helps" the researcher used descriptive percentage analysis. For the presentation of data through the calculation of the percentage with the formula: 


$$
\mathrm{DP}=\frac{n}{N} x 100 \%
$$

DP : Descriptive Percentage (\%) $\mathrm{n}$ : Empirical Score (score obtained)

$\mathrm{N}$ : Maximum score of statement items (Nisriyanan, 2007)

Determination of the criteria for understanding the scale of student reproductive health based on percentages in the following way:

Highest score percentage : $(4: 4) \times 100 \%=100 \%$

Lowest score percentage : $(1: 4) \times 100 \%=25 \%$

Range : $100 \%-25 \%=75 \%$

Interval class length : range : number of criteria $(75 \%: 4=18.75 \%)$

With an interval class length of $75 \%$ and a percentage interval of $18.75 \%$, the criteria for assessing the scale of students' understanding of reproductive health are as follows:

TABLE I

CRITERIA FOR ASSESSMENT OF STUDENTS' REPRODUCTIVE HEALTH

\begin{tabular}{lll}
\multicolumn{2}{c}{ UNDERSTANDING SCALE } \\
\hline No & Percentage & Criteria \\
\hline 1 & $81.25 \%-100 \%$ & Very high \\
2 & $62.5 \%-80.25 \%$ & Tall \\
3 & $43.75 \%-61.5 \%$ & Low \\
4 & $25 \%-42.75 \%$ & Very low \\
\hline
\end{tabular}

To examine the effect of information helps on the level of understanding of adolescent reproductive health, the study used the Wilcoxon signed rank test (Asymp.Sig <0.05).

\section{RESULTS AND DISCUSSION}

\section{Students' Reproductive Health Understanding Level}

Researchers used descriptive percentage analysis to determine the level of understanding of students' reproductive health before being given information helps. From the distribution of the scale, the results are as follows:

TABLE II

Pre-TeSt Results of Students' ReProductive Health

\begin{tabular}{llll}
\multicolumn{4}{c}{ UNDERSTANDING SCALE } \\
\hline No & $\mathbf{n}$ & DP $(\%)$ & Criteria \\
\hline 1 & 11 & 52.38 & Low \\
2 & 12 & 57.14 & Low \\
3 & 11 & 52.38 & Low \\
4 & 11 & 52.38 & Low \\
5 & 9 & 42.86 & Low \\
6 & 11 & 52.38 & Low \\
7 & 12 & 57.14 & Low \\
8 & 12 & 57.14 & Low \\
9 & 8 & 38,10 & Low \\
10 & 10 & 47.62 & Low \\
11 & 12 & 57.14 & Low \\
12 & 10 & 47.62 & Low \\
13 & 12 & 57.14 & Low \\
14 & 10 & 47.62 & Low \\
15 & 10 & 47.62 & Low \\
16 & 13 & 61.90 & Low \\
17 & 9 & 42.86 & Low \\
18 & 13 & 61.90 & Low \\
19 & 10 & 47.62 & Low
\end{tabular}

\begin{tabular}{llll}
20 & 10 & 47.62 & Low \\
21 & 12 & 57.14 & Low \\
22 & 12 & 57.14 & Low \\
23 & 11 & 52.38 & Low \\
24 & 11 & 52.38 & Low \\
25 & 13 & 61.90 & Low \\
26 & 13 & 61.90 & Low \\
27 & 12 & 57.14 & Low \\
28 & 12 & 57.14 & Low \\
29 & 11 & 52.38 & Low \\
30 & 13 & 61.90 & Low \\
31 & 14 & 66.67 & Tall \\
32 & 14 & 66.67 & Tall \\
33 & 13 & 61.90 & Low \\
34 & 14 & 66.67 & Tall \\
35 & 13 & 61.90 & Low \\
36 & 12 & 57.14 & Low \\
37 & 13 & 61.90 & Low \\
38 & 14 & 66.67 & Tall \\
39 & 12 & 57.14 & Low \\
40 & 11 & 52.38 & Low \\
41 & 14 & 66.67 & Tall \\
\hline Average & $\mathbf{1 1 . 7 0 7 3}$ & $\mathbf{5 5 . 7 5}$ & Low \\
\hline & & & \\
\hline
\end{tabular}

Based on table II, it can be seen that the level of understanding of students' reproductive health before being given treatment (information helps) is in the low criteria with an average value of $55.75 \%$. However, there are 5 students who are in the high criteria.

From the results of the interviews obtained, the students did not get information helps about adolescent reproductive health. This causes students to lack understanding of information about women's reproductive health, for example the parts of the female reproductive organs, matters relating to sexually transmitted diseases (STDs), as well as how to prevent these sexually transmitted diseases. Through the results of the interviews above, the researchers provided information helps related to female adolescent reproductive health.

\section{Adolescent Reproductive Health Understanding Level of Students After Information Helps Are Provided \\ After being provided with information helps, the researchers conducted a post-test to determine the level of understanding of students' reproductive health. The following will present the level of understanding of students' reproductive health after being given treatment (information helps).}

TABLE III

Post-Test Results of StUdENTS' RePRoductive HeAlth

\begin{tabular}{llll}
\multicolumn{4}{c}{ UNDERSTANDING SCALE } \\
\hline No. & $\mathbf{n}$ & $\%$ & Criteria \\
\hline 1. & 19 & 90.48 & Very high \\
2. & 18 & 85.71 & Very high \\
3. & 19 & 90.48 & Very high \\
4. & 21 & 100.00 & Very high \\
5. & 20 & 95.24 & Very high \\
6. & 14 & 66.67 & High \\
7. & 18 & 85.71 & Very high \\
8. & 21 & 100.00 & Very high
\end{tabular}




\begin{tabular}{|c|c|c|c|}
\hline 9. & 16 & 76.19 & High \\
\hline 10. & 17 & 80.95 & High \\
\hline 11. & 19 & 90.48 & Very high \\
\hline 12. & 17 & 80.95 & High \\
\hline 13. & 19 & 90.48 & Very high \\
\hline 14. & 13 & 61.90 & Low \\
\hline 15. & 18 & 85.71 & Very high \\
\hline 16. & 21 & 100.00 & Very high \\
\hline 17. & 17 & 80.95 & High \\
\hline 18. & 19 & 90.48 & Very high \\
\hline 19. & 20 & 95.24 & Very high \\
\hline 20. & 17 & 80.95 & High \\
\hline 21. & 20 & 95.24 & Very high \\
\hline 22. & 20 & 95.24 & Very high \\
\hline 23. & 18 & 85.71 & Very high \\
\hline 24. & 19 & 90.48 & Very high \\
\hline 25. & 18 & 85.71 & Very high \\
\hline 26. & 18 & 85.71 & Very high \\
\hline 27. & 18 & 85.71 & Very high \\
\hline 28. & 18 & 85.71 & Very high \\
\hline 29. & 16 & 76.19 & High \\
\hline 30. & 16 & 76.19 & High \\
\hline 31. & 15 & 71.43 & High \\
\hline 32. & 18 & 85.71 & Very high \\
\hline 33. & 21 & 100.00 & Very high \\
\hline 34. & 21 & 100.00 & Very high \\
\hline 35. & 20 & 95.24 & Very high \\
\hline 36. & 15 & 71.43 & High \\
\hline 37. & 14 & 66.67 & High \\
\hline 38. & 17 & 80.95 & High \\
\hline 39. & 12 & 57.14 & Low \\
\hline 40. & 20 & 95.24 & Very high \\
\hline 41. & 19 & 90.48 & Very high \\
\hline Average & 17.95 & 85.48 & Very high \\
\hline
\end{tabular}

Based on table III above, it can be seen that the level of understanding of students' reproductive health after being given treatment (information helps) is in very high criteria with an average value of $85.48 \%$. However, there are still 2 students who are in the low criteria.

Then the researcher conducted another interview with the students who had been given treatment (information helps). Based on the results of the interviews obtained, students revealed a change in understanding that was better than before. Students can have a broader understanding, knowledge and insight about adolescent reproductive health, especially in women. The students were very enthusiastic and wanted to participate in more than three help meetings provided by the researcher.

\section{Analysis of the Wilcoxon Signed Rank Test}

Analysis of the data used to determine whether the effect of information helps on the level of students' understanding of adolescent reproductive health is to test Wilcoxon decision making using the guidelines with significance level $\alpha=5 \%$ (0.05) with the results in the table below:

$$
\text { TABLE IV }
$$

WILCOXON SIGNED RANK TEST RESULTS

\begin{tabular}{lllll}
\hline $\begin{array}{l}\text { Wositive } \\
\text { Ranks }\end{array}$ & $\begin{array}{l}\text { Negative } \\
\text { Ranks }\end{array}$ & $\begin{array}{l}\text { Mean } \\
\text { Rank }\end{array}$ & Z & $\begin{array}{l}\text { asymp. Sig. } \\
\text { (2-tailed) }\end{array}$ \\
\hline 40 & 0 & 20,50 & $-5,530$ & 0.000 \\
\hline
\end{tabular}

Based on table 3 above, it can be seen that the results of the positive ranks or the difference (positive) in the pretest and posttest for the level of understanding of students' reproductive health have increased. The average increase is 20.50. Then, it is known that the value of Asymp. Sig. (2tailed) of 0.000 where $<0.05$, then there is a difference between the level of understanding of adolescent reproductive health of students for pretest and posttest. So it can be concluded that there is an influence of reproductive health information helps with the influence of information helps on the level of understanding of adolescent reproductive health.

\section{Discussion}

Information helps to see the effect on the level of understanding of adolescent reproductive health of students is an effort to provide assistance to students by providing information or knowledge needed by students. The aim is that students are able to understand and have knowledge about the importance of adolescent reproductive health and are able to maintain and care for the reproductive organs to avoid sexual diseases or other unwanted things.

Based on the results of the study, it can be seen that before information helps were provided, the level of understanding of adolescent reproductive health was included in the Low criteria with an average value of $55.75 \%$. This is in line with the results of research by Astika \& Sutijono (2013) that there are students who have a low level of understanding of reproductive health before being provided with information helps. Furthermore, the results of research by Sari, et al (2017) that the understanding of adolescent reproductive health of students is still low and very low. This is because there are still students who do not get information about adolescent reproductive health so that it triggers errors in responding to adolescent reproductive health. The provision of information helps on adolescent reproductive health is expected to provide students with an understanding of matters relating to reproductive health aspects that must be known and prevent students from harm due to lack of understanding of reproductive health, especially for adolescent students. To follow up on this matter, information helps on reproductive health for female adolescents were provided for three meetings.

Then after being provided with information helps, the level of understanding of adolescent reproductive health is very high with an average score of $85.48 \%$. This shows that overall students already have an understanding and knowledge of reproductive health, especially in women. In line with the results of research conducted by Nurhalimah (2013), that private field guidance information helps can be used to help students increase their understanding of the impact of free sex behavior. This proves that after students are provided with information helps, there is an increase in the level of understanding of reproductive health.

The results of research conducted by Sari, et al (2017) can be concluded that there is a positive influence of adolescent reproductive health information helps on the level of 
understanding of student adolescent reproductive health. The connection with this research is that information helps affect the level of understanding of adolescent reproductive health of students.

Based on research conducted by Nikmah (2016), Sari, et al (2017) information helps are one of the guidance and counseling helps that can be provided to students to improve students' understanding and knowledge. According to Mugiarso (2006: 56) information helps have an understanding function, which helps students provide an understanding of themselves and their environment as well as a prevention function, which can prevent students from doing things that deviate and are not in accordance with the norms in society. So overall, with the provision of information helps, students can gain an understanding of the material presented, namely the understanding of women's reproductive health. In addition, with the prevention function so that students are able to avoid irresponsible behavior towards their own reproductive health.

\section{CONCLUSION}

Based on the results of research and discussion on the effect of information helps on the level of understanding of students' reproductive health, it can be concluded that the level of understanding of students' reproductive health before being provided with information helps is low and after the information helps provided can increase the level of understanding of adolescent reproductive health.

\section{REFERENCES}

Astika, T. S., \& Sutijono, H. (2013). Penerapan Layanan Informasi Untuk Meningkatkan Pemahaman Kesehatan Reproduksi Pada Siswa Kelas XI IS-3 SMAN 1 Pacet Mojokerto. BK UNESA, 03(01), 445-453.

Azhar, S. K. (2017). Persepsi Siswa Tentang Layanan Informasi Kesehatan Reproduksi Remaja Yang Diberikan Guru BK SMAN 1 Kubung. Konselor, 2(1), 146-150.

Dini, M., Wijaya, T. T., \& Sugandi, A. I. (2018). Pengaruh Self Confidence Terhadap Kemampuan Pemahaman Matematik Siswa SMP. Jurnal Silogisme, 3(1), 1-7.

Ernawati, H. (2018). Pengetahuan Kesehatan Reproduksi Remaja di Daerah Pedesaan 1. Indonesian Journal for Health Sciences, 02(01), 58-64.

Hazar, S., Astuti, I., \& Yuline. (2013). Layanan Informasi Oleh Guru BK Tentang Kesehatan Reproduksi Remaja Pada Siswa Kelas VIII Mts N 1 Mempawah. Jurnal Pendidikan Dan Pembelajaran (JIPP), 7(1), $1-10$.

Mugiarso, H. (2006). Bimbingan dan Konseling. Semarang: UPT UNNES Press.

Nikmah, N. (2016). Keefektifan Layanan Informasi Untuk Meningkatkan Pemahaman Kesehatan Reproduksi
Siswa Kelas 9 SMP N 1 Bonang Demak Tahun Ajaran 2015/2016. Skripsi. UNS.

Nisriyana, E. (2007). Hubungan Interaksi Sosial Dalam Kelompok Teman Sebaya Dengan Motivasi Belajar Siswa Kelas IX Di SMP Negeri I Pegandon Tahun Pelajaran 2006/2007. Skripsi Jurusan Bimbingan dan Konseling Fakultas Ilmu Pendidikan Universitas Negeri Semarang. Semarang: Tidak Diterbitkan.

Nurhalimah, S. (2013). Penerapan Layanan Informasi Bimbingan Pribadi untuk Meningkatkan Pemahaman Siswa Mengenai Dampak Perilaku Seks Bebas di SMAN 1 Sugihwaras Bojonegoro. Ejournal.Unesa.Ac.Id, 04(01).

Sari, I. D., Munir, A., \& Munifah. (2017). Pengaruh Layanan Informasi Kesehatan Reproduksi Terhadap Tingkat Pemahaman Kesehatan Reproduksi Pada Siswa Kelas X AP 3 SMK Negeri 2 Palu. Konseling \& Psikoedukasi, 2(1), 1-14.

Sukitman, T. (2015). Panduan Lengkap dan Aplikatif Bimbingan Konseling Berbasis Pendidikan Karakter. Yogyakarta: DIVA Press.

Tohirin. (2014). Bimbingan dan Konseling di Sekolah dan Madrasah (Berbasis Integrasi). Jakarta: PT Raja Grafindo Persada.

Widyastuti. (2009). Kesehatan Reproduksi. Yogyakarta: Fitra Maya

Wijaya, I. M. K., Agustini, N. N. M., \& Tisna, G. D. (2014). Pengetahuan, Sikap Dan Aktivitas Remaja SMA Dalam Kesehatan Reproduksi Di Kecamatan Buleleng. Jurnal Kesehatan Masyarakat, 10(1), 3342.

Winkel, W.S., \& Hastuti. S. (2005). Bimbingan dan Konseling di Institusi Pendidikan. Yogyakarta: Media Abadi. 